\title{
Uterine rupture a retrospective analysis of referral cases at a tertiary care centre in Kanpur city
}

\author{
Seema Dwivedi, Anil Kumar* \\ Upper India Sugar Exchange Maternity Hospital, GSVM Medical College, Kanpur, UP, India
}

Received: 10 June 2015

Revised: 21 June 2015

Accepted: 10 July 2015

\section{*Correspondence:}

Dr. Anil Kumar,

E-mail: dr.anilkumar111@gmail.com

Copyright: ( $)$ the author(s), publisher and licensee Medip Academy. This is an open-access article distributed under the terms of the Creative Commons Attribution Non-Commercial License, which permits unrestricted non-commercial use, distribution, and reproduction in any medium, provided the original work is properly cited.

\begin{abstract}
Background: Uterine rupture a retrospective analysis of referral cases at a tertiary care centre in Kanpur city.

Method: Observational study was conducted on 40 patients admitted Upper India Sugar Exchange Maternity Hospital, Kanpur.

Result: Majority of patients presented with rupture uterus belongs to age group 30-35 years were multigravida came from rural setup and were unbooked among patients with lower segment rupture, $66.7 \%$ needed operative hysterectomy while $33 \%$ needed rent repair alone and were treated successfully.

Conclusion: Uterine rupture is a catastrophic complication associated with high fetal and maternal morbidity and mortality.
\end{abstract}

Keywords: Previous ceasarean scar, Obstructed labour hysterectomy

\section{INTRODUCTION}

Uterine rupture in pregnancy is a rare and often catastrophic complication. It is associated with a high incidence of foetal and maternal morbidity. Several factors are known to increase the risk of uterine rupture, these include poor socio-economic conditions uncontrolled fertility, illiteracy and unsupervised labour and contracted pelvis. Uterine rupture during pregnancy is a rare occurrence whereas uterine scar dehiscence is more common and seldom results in major maternal or foetal complication. The rate of caesarean has risen from $5 \%$ in 1970 to $26 \%$ in 2003 despite improvement in obstetrical procedures such as external version, total breech extraction etc.

Incidence of rupture uterus is one in 1146 pregnancies i.e. $0.07 \%$. The incidence of rupture remains high mainly due to the use of oxytocin drug by people not qualified for its use. Several studies suggest that for adequately screened women with prior caesarean section in trial of labour is safer than elective repeat caesarean section in hospital environment, but due to lack of health education, ignorance or poverty, women in our country do not come for regular antenatal check up preferring home delivery by traditional birth attendant, instead of coming to hospital for trial of scar. They were brought to hospital after prolonged dysfunctional labour when traditional birth attendant failed to deliver them. This results in increased chances of rupture of previous caesarean scar. High maternal mortality and morbidity rate is a consequence of poor maternal care, inadequate socio-economic and environmental conditions poor accessibility to health service and poor nutritional habits. Contributing factors are also extremes of maternal age and too many births with in short intervals. 
Early diagnosis of the condition and treatment results in better chances of maternal and fetal outcome.

The objective of the study was to identify the risk factors for uterine rupture in labour to report maternal and foetal outcome and to identify preventive measures.

\section{METHODS}

This was a retrospective study conducted on 40 patients referred with uterine rupture to UISEMH from 2009 to 2013.

The protocol followed for management of uterine rupture was immediate exploratory laparotomy with all preoperative preparations, blood in hand and expert anaesthetists supervision to stabilize patient's vitals pre and per-operatively.

Most of the patients could be managed by Rent repair or hysterectomy as per the location of rupture.

\section{RESULTS}

Majority of patients presenting with rupture uterus belonged to age group $30-35$ years $(62.5 \%)$ were multigravida (95\%), came from rural setup (85\%) and were unbooked (95\%).

Majority of deliveries complicating to uterine rupture took place at home $(75 \%)$ delivered by dais.

Causes leading to uterine rupture in our study was mainly obstructed labour $(60 \%)$, followed by previous LSCS (37.5\%), H/o MTP in patients was a rare but important cause of uterine rupture in primigravida patient. Another important cause of rupture uterus was use of syntocinon at peripheries by dais. Most of the patients suffered due to delay in diagnosis (77.5\%) at PHC and $\mathrm{CHC}$ delay in their transport, as a result two patients were brought dead.

At the time of admission majority presented with $\mathrm{PPH}$ $(55 \%)$ and shock $(45 \%)$.

The interventions done for management of rupture uterus was stabilizing the patients vitals and taking the patient for exploratory laparotomy. Per-operatively, majority of patient had lower segment rupture (90\%). Followed by an equal proportion of those who had upper segment rupture $(5 \%)$ alone or both upper and lower segment involved (5\%). Among patient with lower segment rupture, $66.7 \%$ needed operative hysterectomy while $33 \%$ needed rent repair alone and were treated successfully.

\section{Observation}

Total no. of patients $=40$

5 yrs $-2009-2013$
Table 1: Demographic profile.

\begin{tabular}{|c|c|c|c|}
\hline \multicolumn{2}{|c|}{ Parameters } & $\begin{array}{l}\text { No. of } \\
\text { patients }\end{array}$ & $\begin{array}{l}\text { Percentage } \\
\text { of patients }\end{array}$ \\
\hline Age & $\begin{array}{l}20-25 \text { Yrs } \\
25-30 \text { yrs } \\
30-35 \text { yrs } \\
35-40 \text { yrs }\end{array}$ & $\begin{array}{l}1 \\
2 \\
25 \\
12\end{array}$ & $\begin{array}{l}2.5 \\
5 \% \\
62.5 \% \\
30 \%\end{array}$ \\
\hline Parity & $\begin{array}{l}\text { Primi } \\
\text { Multi }\end{array}$ & $\begin{array}{l}2(\mathrm{H} / \mathrm{o} \mathrm{MTP}) \\
38 \mathrm{G}_{2}-5 \\
95 \% \mathrm{G}_{3}-33\end{array}$ & $\begin{array}{l}5 \% \\
13.15 \% \\
86.84 \%\end{array}$ \\
\hline $\begin{array}{l}\text { Socio- } \\
\text { economic }\end{array}$ & $\begin{array}{l}\text { Rural } \\
\text { Urban }\end{array}$ & $\begin{array}{l}34 \\
06\end{array}$ & $\begin{array}{l}85 \% \\
15 \%\end{array}$ \\
\hline Admission & $\begin{array}{l}\text { Booked } \\
\text { Unbooked }\end{array}$ & $\begin{array}{l}02 \\
38\end{array}$ & $\begin{array}{l}5 \% \\
95 \%\end{array}$ \\
\hline
\end{tabular}

Table 2: Deliveries complicating to uterine rupture.

\begin{tabular}{|lll|}
\hline $\begin{array}{l}\text { Parameters (Patients } \\
\text { with rupture referred } \\
\text { from) }\end{array}$ & $\begin{array}{l}\text { No. of } \\
\text { patients }\end{array}$ & $\begin{array}{l}\text { Percentage } \\
\text { of pts }\end{array}$ \\
\hline Home (dai handled) & 30 & $75 \%$ \\
\hline PHC & 04 & $5 \%$ \\
\hline CHC & 03 & $7.5 \%$ \\
\hline Tertiary & 03 & $7.5 \%$ \\
\hline
\end{tabular}

Table 3: Causes leading to uterine rupture.

\begin{tabular}{|c|c|c|}
\hline Parameter & $\begin{array}{l}\text { No. of } \\
\text { patients }\end{array}$ & $\begin{array}{l}\text { Percentage } \\
\text { of patients }\end{array}$ \\
\hline 1. Obstructed labor & 24 & $60 \%$ \\
\hline $\begin{array}{l}\text { a) Malpresentation \& } \\
\text { Malposition }\end{array}$ & 12 & $50 \%$ \\
\hline b) Contracted Pelvis & 5 & $20.83 \%$ \\
\hline c) Big Size baby & 4 & $16.66 \%$ \\
\hline d) Hydrocephalus & 3 & $12.5 \%$ \\
\hline 2. Previous LSCS & 15 & $37.5 \%$ \\
\hline 3. Cervical dystocia & 1 & $2.5 \%$ \\
\hline 4. Misoprost use & 2 & $5 \%$ \\
\hline $\begin{array}{l}\text { 5. Syntocinon use at } \\
\text { periphery }\end{array}$ & 21 & \multirow{3}{*}{$6 \%$} \\
\hline \multirow{2}{*}{$\begin{array}{l}\text { Intramuscular } \\
\text { In drip }\end{array}$} & 17 & \\
\hline & 04 & \\
\hline 6. Prev. H/o MTP & 02 & \\
\hline
\end{tabular}

Table 4: Causes of delay in management.

\begin{tabular}{|lll|}
\hline Parameters & $\begin{array}{l}\text { No. of } \\
\text { patients }\end{array}$ & $\begin{array}{l}\text { Percentage } \\
\text { of pts }\end{array}$ \\
\hline Delay in diagnosis & 31 & $77.5 \%$ \\
\hline $\begin{array}{l}\text { Delay in Management at } \\
\text { Primary and secondary } \\
\text { health care centre }\end{array}$ & 15 & 37.5 \\
\hline Delay in transportation & 33 & 82.5 \\
\hline
\end{tabular}


Table 5: Condition at time of admission.

\begin{tabular}{|lll|}
\hline Parameters & $\begin{array}{l}\text { No. of } \\
\text { patients }\end{array}$ & $\begin{array}{l}\text { Percentage } \\
\text { of pts }\end{array}$ \\
\hline Stable vitals & 7 & $\begin{array}{l}17.5 \text { Pain } \\
\text { abdomen-85\% }\end{array}$ \\
\hline PPH & 22 & $55 \%$ \\
\hline Shock & 18 & $45 \%$ \\
\hline Low G.C. & 15 & $37.5 \%$ \\
\hline Brought dead & 02 & $5 \%$ \\
\hline
\end{tabular}

Table 6: Per-operative findings and operative management.

\begin{tabular}{|llll|}
\hline $\begin{array}{l}\text { Parameter } \\
\text { s }\end{array}$ & $\begin{array}{l}\text { No. of } \\
\text { patient } \\
\text { s }\end{array}$ & $\begin{array}{l}\text { Operative } \\
\text { Management }\end{array}$ & \\
\hline & Hysterectom & $\begin{array}{l}\text { Rent } \\
\text { repair }\end{array}$ \\
\hline $\begin{array}{l}\text { Upper } \\
\text { Segment } \\
\text { Rupture }\end{array}$ & $2(5 \%)$ & 1 & 1 \\
\hline $\begin{array}{l}\text { Lower } \\
\text { segment } \\
\text { rupture }\end{array}$ & $\begin{array}{l}(90 \%) \\
\begin{array}{l}\text { Upper and } \\
\text { lower } \\
\text { segment }\end{array}\end{array}$ & $24(66.67 \%)$ & $\begin{array}{l}12 \\
(36.3 \%\end{array}$ \\
\hline
\end{tabular}

Parameter

$\begin{array}{cc}\text { Blood Transfusion } & 40 \\ <3 \text { units } & 21 \\ >3 \text { units } & 19\end{array}$

Table 7: Outcome in terms of maternal mortality and morbidity and neonatal outcome.

\begin{tabular}{|lll|}
\hline Parameters & $\begin{array}{l}\text { No. of } \\
\text { patients }\end{array}$ & $\begin{array}{l}\text { Percentage } \\
\text { of pts }\end{array}$ \\
\hline Uneventful & 7 & 17.5 \\
\hline $\begin{array}{l}\text { Sepsis in post op } \\
\text { period }\end{array}$ & 23 & 57.5 \\
\hline Burst abdomen & 03 & $7.5 \%$ \\
\hline Renal failure & 02 & $5 \%$ \\
\hline Vesico-vaginal fistula & 02 & $5 \%$ \\
\hline Deaths & 02 & $5 \%$ \\
\hline Dead born fetuses & 36 & $90 \%$ \\
\hline Neonatal survival & 04 & $10 \%$ \\
\hline
\end{tabular}

\section{DISCUSSION}

Uterine rupture is a life threatening obstetrical emergency encountered infrequently in the emergency department where the diagnosis is often missed or delayed, leading to maternal and fetal mortality and / or morbidity.

Our study was conducted in department of Obstetrics of GSVM Medical College, Kanpur for a period of 4 years from January 2009 to December, 2013, total number of patients in this study were 40 .

Table 1 shows the demographic profile of our patients. Most of our patients fell into the age group of $30-35$ years $(62.5 \%)$, and $35-40$ years $(30 \%)$. Most of the patients were multiparous with $86.84 \%$ patients with parity of 3 . This is consequent with the findings of Sweeten KM et $\mathrm{al}^{1}$. In a study by Isharq et $\mathrm{al}^{2} 64.9 \%$ patients with rupture uterus had parity of 5 and above. In the same study it was concluded that women older than 35 and women having their $5^{\text {th }}$ birth are at greatest risk for uterine rupture.

Table 1 also highlights that $85 \%$ patients belonged to rural area where there was poor outreach to antenatal services.

In a study conducted by $\mathrm{UNICEF}^{3}$ and Raczynski $\mathrm{A}$ et $\mathrm{al}^{4}$ it was conducted that rural reas have highest incidence of rupture uterus. In our study it was found that $95 \%$ of patients with rupture uterus were unbooked which again reflects the poor utilization of antenatal services. Our findings are consequent with the study conducted by Mulumba $\mathrm{N}^{5}$,

Table 2 shows the place of referral $75 \%$ of patients had history of dai handling $5 \%$ patients were referred from PHC 7.5\% were those from tertiary health centre, most of which were being given trial of VBAC. In a study conducted by Mukasa et $\mathrm{al}^{6}$ it was found that if the distance of referral was more than $5 \mathrm{kms}$ the odds ratio for uterine rupture were 10.86 .

Table 3 shows the cases leading to uterine rupture. In our study $60 \%$ of patients with uterine rupture were of obstructed labour. The factor contributing to obstructed labour were malpresentation $(50 \%)$, contracted pelvis $(20.83 \%)$, big size baby $(10.66 \%)$, and hydrocephalus $(12.5 \%)$. In a study by Sameera et ${ }^{\text {a17 }}$ on 34 patients it was found that obstructed labour was the leading cause of rupture is unscarred uterus $(26.47 \%, 9 / 34), 3$ cases was due to contracted pelvis, 2 due to transverse lie and 1 due to hydrocephalic baby. Ishraq et $a 1^{2}$ found obstructed labour as the cause of rupture uterus in $83.3 \%$ of their patients. Another study conducted by Deneke et $\mathrm{al}^{8}$ concluded that obstructed labour can cause upto $93 \%$ of uterine rupture.

$37.5 \%$ of patients is our study had a previous cesarean scar Sameera et al' attributed $14.7 \%$ of ruptured uterus to previous LSCS scar Golan et $\mathrm{a} 1{ }^{9}$ noted that among 126 , seven-third deliveries, oxytocin was used in 26 of 61 cases $(43 \%)$ that involved unscarred uterine rupture. However Plauche et al $^{10}$ attributed only 1 of 23 unscarred uterine rupture $(4 \%)$ to use of oxytocics. The latter matches our findings. We found that $5 \%$ cases of rupture were associated with misoprost while $6 \%$ were associated with syntocinon there at periphery. Our study also found that $2.5 \%$ cases were due to cervical dystocia while 2 
patients had history of previous MTP Ishraq et a1..$^{2}$ found history of curettage is $22.2 \%$ of uterine rupture.

Table 4 highlights the causes of delay in management Majority patients $(77.5 \%)$ sufferred with delay in diagnosis. $37.5 \%$ patients were victims of delay in management in PHC and CHC. $82.5 \%$ had delay in transportation. The study by Ishraq et al' throws light at the delay in exact diagnosis. They concluded that abdominal examination has lowest diagnostic reliability. Reliability was increased by vaginal examination.

Table 5 focuses on the condition at the time of admission $17.5 \%$ had stable vitals and complained mainly of pain abdomen, $55 \%$ had post partum haemorrhage. Nearly $45 \%$ patients had shock $37.5 \%$ patients presented with low general condition. $5 \%$ of patients with rupture uterus were brought dead to the hospital. These again reflect the poor prognosis of these cases.

Table 6 reveals upper segment rupture in 5\% (2/40) cases one patient was which manged by hysterectomy $\&$ other by rent repair managed by Majority of pts (90\%) had lower segment rupture, two-third of which underwent hysterectomy \& one third had rent repair $5 \%$ patients (2/40) had upper \& lower segment rupture managed by hysterectomy. Classical cesarean delivery via vertical midline uterine incision is infrequently performed in modern era and currently amount for $0.5 \%$ of all births in $\mathrm{US}^{11}$.

ACOG reports 4-9\% rate of frank uterine rupture in women with classic cesarean delivery. In a study of 20095 women by Lydon Rochdlle et al spontaneous uterine rupture rate in patients with single cesarean delivery scar who underwent schedule repeat cesarean section without of trial of labour was $0.16 \%{ }^{2}$

In study by Olaglouji et al ${ }^{13}$ incidence of uterine rupture in previous lower segment scar was $2.4 \%$ in labour induced women. Ishraq et $\mathrm{a}^{2}$ reported $45.7 \%$ patients had rent repair with tubal ligation, $14.3 \%$ had total hysterectomy in $5.7 \%$ had subtotal hysterectomy. Total rate of hysterectomy in our study was $65 \%$ Leung et a $1^{14}$ reported $19 \%$ patients were managed with hysterectomy. Blood availability and transfusion in uterine rupture is a life saving factor. In our study total of 40 unit blood was transfused with 21 patients requiring <3units and 19 patients required $>3$ units. Ishraq et a12 reported $57.1 \%$ patients required transfusion of 500 to $1000 \mathrm{ml}$ of blood before and during operation.

Table 7 shows outcome in terms of maternal mortality and morbidity and neonatal outcome. In our study, $57.5 \%$ patients had sepsis in post operative period which is further precipitated by low haemoglobin status $7.5 \%$ patients had burst abdomen which is not shocking given the high rate of puerperal sepsis $5 \%$ patients each had renal failure and vesicovaginal fistula, maternal mortality was reported to be $5 \%$. Maternal death as a consequence of uterine rupture occurs at a rate of $0-1 \%$ in modern developed nations, but mortality rates in developing countries are 5-10\% ${ }^{15-16}$.

$90 \%$ of fetal were dead born. Neonatal survival was only $10 \%$. In studies reported before 1978 fetal mortality rate associated with uterine rupture was high. In a review of 33 studies by Schrinsky and Benson, 960 cases of uterine rupture resulted in 620 infant deaths, yielding a perinatal mortality rate of 65\%". In 1993 Leung et al. reported that $6 \%$ perinatal deaths occurred in patients who had uterine rupture. Landon et al. reported a perinatal death rate from uterine rupture of $2 \%$ among 19 academic centers in US. These studies indicate that the incidence of perinatal death associated with uterine rupture is decreasing in modem era.

\section{CONCLUSION}

Uterine rupture is a catastrophic complication associated with high fetal and maternal morbidity and mortality.

Most of the patients who are referred to our hospital with uterine rupture are multigravida (95\%) with poor socioeconomic status where delivery is being conducted by dias at home (75\% patients). The main factor limiting management is delay in diagnosis and transportation of the total 40 patients referred to our side, 38 lives were saved i.e. $95 \%$. The main morbidity in post-operative period was sepsis $(57.5 \%)$.

Delay in diagnosis and referral from periphery are the main factors limiting management at tertiary centre. To conclude, watchfulness of the health professional conducting labour and prompt referral in case of obstructed labor and patients with previous LSCS with possibility of rupture is the only way by which uterine rupture, which is an obstretical emergency, could be prevented and death more judiciously with better patient outcome.

The untrained dias conducting home deliveries and staff at $\mathrm{PHC}$ and $\mathrm{CHC}$ need to be adequately educated about the early diagnosis and resuscitation of the patients landing into uterine rupture. It is imperative that they can identify this obstetric emergency so that patient reaches tertiary centre well in advance. This will definitely reduce fetal and maternal mortality and morbidity.

Funding: No funding sources

Conflict of interest: None declared

Ethical approval: The study was approved by the Institutional Ethics Committee

\section{REFERENCES}

1. Sweeten KM, Grapes WK, Athanassiou A: Spontaneous rupture of the unscarred uterus. AM J Obstet Gynecol. 1995;172:1851-6. 
2. Ishraq Dhaifalah, Jiri Santavy, Helena Fingerova : Uterine rupture during pregnancy and delivery among women attending the altthawara hospital in sana's city yemen republic. Biomed Pap Med Fac Urine Palaky Olumouc Caoch Rspub. 2006;150(2):79283.

3. UNICEF. The state of the world;s children Report oxford university. Press New York. 1996.

4. Racyynski A et al. An assessment of the incidence of hemorrhage as a cause of maternal mortality in Poland 1985-1990, Acta obstetet Gynecolocia. 1997;76:24.

5. Mulumba N. Rupture of the uterus. BMJ. 196; 312: 1204-5.

6. Peter K Hukass: uterine rupture is a teaching hospital is Mbarara Hukasa et al: reproduce health 2013; 10:21.

7. Sameera Khan, uterine rupture a review of 34 cases of Ayub teaching hospital. Abbottabad.

8. Deneke F. Frief communication, ruptured uterus in Ethiopia. Int. J Gyn Obst, 1996; 54: 175-176.

9. Golan A et al. Rupture of pregnant uterine. Obstet gynecol Nov. 1980; 56(5) : 549-54.

10. Plauche WC et al. Catastrepphic uterine rupture. Obstet Gynecol. 1984; 64(6) : 702-7.

11. Chauhan SP, Magan EF, et al. Pregnancy after classical cesarean. Obstet Gynecol, New 2002; 100(5): 946-50.
12. Tydon Rochdle et al. Risk of uterine rupture during labor among women with a prior cesarean delivery. N Engl J Med. 2001;345(1):3-8.

13. Broden Nelson Alaglauj et al : Uterine rupture and risk factors for cesarean delivery following reduced labour is women with one previous lower segment cesarean section. Pubmed, BOI : 10.3109/14767058. 2012, 666593

14. Leung AA et al. Uterine rupture after previous cesarean delivery. Maternal \& Fetal consequences. Am J Obstet Gynecol. 1998;169(4):94-50.

15. Mokgokong ET et al. Treatment of ruptured uterus. S Afr Med J. 1976;50(41):1621-4.

16. Rahman $\mathbf{J}$ et al : Rupture of uterus is labor. A review of 96 cases. Acta Obstet Gynecol Scnd. 1985;64(4):311-5.

17. Schrinsky DC, et al: Rupture of pregnant uterus : a review. Obstet Gynecol Surv. 1978;33(4):217-32.

18. London $\mathrm{MB}$ et al. Maternal \& provided outcomes associated with trial of labour after prior cesarean delivery. N Engl J Med. 2004;351(25):2881-9.

Cite this article as: Dwivedi S, Kumar A. Uterine rupture a retrospective analysis of referral cases at a tertiary care centre in Kanpur city. Int J Reprod Contracept Obstet Gynecol 2015;4:1148-52. 